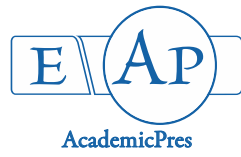

\title{
Floristic Diversity and Vegetation Analysis of Plants from Various Forest Types in Hosur Forest Division, Tamil Nadu, Southern India
}

\author{
Umeshkumar L. TIWARI ${ }^{1 *}$, Kaliamoorthy RAVIKUMAR ${ }^{2}$ \\ ${ }^{1}$ Botanical Survey of India, Arunachal Pradesh Regional Centre, Senki View, Itanagar-791111, Arunachal Pradesh, \\ India; tigerumesh11@gmail.com (*0rrespondingauthor) \\ ${ }^{2}$ Institute of Trans-Disciplinary Health Sciences and Technology (ITDHST) University, National Herbarium of Medicinal Plants and \\ Repository of Raw Drug, Foundation for Revitalisation of Local Health Traditions (FRLHT), No. 74/2, Jarakabande Kaval, Post Attur, \\ Via-Yelahanka, Bangalore 560 106, India; ravikumarfrlbt@gmail.com
}

\begin{abstract}
The study deals with the floristic diversity assessment and vegetation composition analysis in various forest types from Hosur Forest division situated in Eastern Ghats of Southern India, in the state of Tamil Nadu. The study recorded 468 species of plants belonging to 283 genera and 91 families, including Angiosperms (464 species), Pteridophytes (3 species) and Bryophytes (1 species). Of the total, 94 species are trees, 12 are lianas, 70 are shrubs, 34 species are climbers, 194 species are herbs, sedges 7, grasses 21, ferns 3 and 1 species of moss. The five most abundant families in Hosur Forest Division were Fabaceae ( 45 spp.), Poaceae (34 spp.), Acanthaceae (30 spp.), Euphorbiaceae (28 spp.) and Rubiaceae (25 spp.). The quantitative features such as density and important value index (IVI) varied greatly among forest and in different forest types. In the present study, the diversity index of shrubs and herbs were found to be higher than that of trees. The maximum species diversity was recorded in Southern dry mixed deciduous forest (SDMDF) followed by Southern Thorn Forest (STF) and Southern Thorn Scrub (STS). The species diversity (H) was recorded the highest for SDMDF (5.61) followed by STF (5.18) and the lowest for STS (5.12). The presence of large number of higher girth class tree species and low number of sapling and seedling indicates that the present forests investigated are old and exhibiting low regeneration.
\end{abstract}

Keywords: Eastern Ghats; native; rarity; tropical forest

\section{Introduction}

Forests provide the basic life support system to all the living entities of mother nature, including mankind; these ecosystems provide fresh air, water resources, fertile soil, biodiversity and environment. Vast sections of rural society, including a majority of the tribal groups, are directly reliant on forests for their livelihood. Forest degradation will have adverse impact on these life supporting systems. It is known that for the biodiversity conservation in the state of Tamil Nadu the protected areas account only $4.2 \%$ of its total geographical areas, against the national average of $4.82 \%$. Thus, there is need of increasing the PAN (Protected Area Network) in the state to achieve the target and thus will also help to conserve biological diversity for future.

India is a signatory to three international conventions namely Convention on Biological Diversity (CBD), the Convention on Wetlands of International Importance (Ramsar Convention) and the United Nations Framework Convention on Climate Change (UNFCCC) (Anderson, 2002). Biodiversity conservation has been strongly emphasized since Agenda 21 of the Rio Summit 1992. Hence, it is essential to address the important thrust area for the conservation of biological diversity in the country. Tropical forest constitutes the most diverse plant communities on Earth and it covers $7 \%$ of the land surface, while harboring more than half of the world's species (Wilson, 1988). Never the less, they are currently vanishing at an overall rate of $0.8-2 \%$ per year (May and Stumpf, 2000; Sagar et al., 2003). The vanishing of tropical forests comes at a time when our data on their structure and dynamics is sadly not enough (Hubbell and Foster, 1992). Several authors like Jayakumar et al. (2002), Pragasan and Parthasarthy (2010) say that the pressure on forests by the ever-increasing population is logarithmic and well predicted. Due to heavy dependency on forest and rapidly dwindling biodiversity levels, species loss could sooner or later lead to ecosystem collapse (Naeem and Wright, 2003); a decade of research has highlighted generally a positive relationship (Hooper et al., 2005; Balvanera et al., 2006). Across the world, 35 biodiversity hotspots have been identified on the basis of the species endemism and degree of threat through 
598

habitat loss (Myers et al., 2000) and India is one of the 12 mega diversity countries in the world. Among the rich biodiversity hotspots in India are included the Eastern and Western Ghats, Western and Eastern Himalayas and Andaman islands. The present study site falls within the Eastern Ghats.

Conservation of biological diversity has become a major concern, for a large part of the society and many government agencies at all levels (Kaya and Raynal, 2001; Tiwari and Ravikumar, 2018). Documenting basic patterns of biodiversity are fundamental for showing potential areas for conservation and management action (Villasenor et al., 2007). The Eastern Ghats of India is a broken chain of hills that runs almost parallel with the East coast of India covering five states viz. Odisha, Telangana, Andhra Pradesh, Tamil Nadu and Karnataka. Floristic diversity and threat status of plants study of Dharmapuri forest Division was done by Tiwari and Ravikumar (2018) and the present study is the extension of that work to another forest division in order to assess plant biodiversity and vegetation analysis in different forest types of Hosur Forest Division.

\section{Materials and Methods}

Study area

Hosur Forest Division (HFD) lies between the latitudes $12^{\circ} 7^{\prime} \& 12^{\circ} 44^{\prime} \mathrm{N}$ and $77^{\circ} 30^{\prime} \& 78^{\circ} 27^{\prime} \mathrm{E}$ (an area of 155,253 ha.). It is bounded on the North and West by the Karnataka State and a portion of Krishnagiri range that adjoins Andhra Pradesh in the North-Eastern portion of the division. The river Cauvery that flows between Karnataka and Tamil Nadu States forms the South-Western boundary of the division. The Melagiris are a group of hills lying nestled between the Cauvery and Chinnar rivers, to the South-East of Hosur taluk in Tamil Nadu, India. The Melagiris form part of an almost unbroken stretch of forests connecting Bannerghatta National Park (which forms its North-Western boundary) to the forests of Cauvery Wildlife Sanctuary (which forms its southern boundary, separated by the river Cauvery) and further to Biligirirangan hills and Sathyamangalam forests. The northern and western parts are comparatively plain and are part of the Mysore plateau.

The average elevation in this region is $500-1,000 \mathrm{~m}$. Ground sinks to $300 \mathrm{~m}$ in the valley of the Cauvery and the highest point is the peak of Guthereyan at 1,395.11 m. Red sandy loam is the most common soil type found in this region. Small deposits of alluvium are found along Cauvery and Chinnar rivers and Kaoline is found in some areas near Javalagiri. The temperature ranges between $10-35{ }^{\circ} \mathrm{C}$. South-West monsoon is fairly active, mostly in the northern areas, but North-East monsoon is distinctly more effective in the region. Average rainfall is $62-360 \mathrm{~mm}$, but some pockets in Denkanikottai range receive up to $1,000 \mathrm{~mm}$ rainfall.

The Hosur division exhibits considerable variation in composition, quantity and condition. The bulk of the forest is predominantly either of the Southern Dry Mixed Deciduous Type (5A/C3). Southern Tropical Riverine Forests (5/B1) form a narrow strip along Cauvery and Chinnar rivers. Southern Tropical Dry Evergreen Forests $(7 / \mathrm{C} 1)$ are found in some sheltered pockets in
Denkanikottai range where rainfall is around $1,000 \mathrm{~mm}$ and elevation is between $800-1,315 \mathrm{~m}$.

Southern Tropical Dry Deciduous Scrub Forests (5A/DS1) are seen mostly near forest borders and Southern Tropical Riverine Forest (5/B1). Hardwickia binata, Terminalia arjuna, Tamarindus indicus, Garcinia gummigutta, Shorea roxburghii, Santalum album and bamboo are some of the important flora found in the area. According to the revised survey of the forest types of India by Champion and Seth (1964), the division is represented by 14 different forest types (Fig. 1). The study area is dominated by Southern Tropical Dry Mixed Deciduous Forest, Hardwickia subtype, Secondary Dry Deciduous Forest, Dry Deciduous Scrub, Dry Tropical Riverine Forest, Southern Thorn Forest, Southern Thorn Scrub Forest, Dry Bamboo Brake, Carnatic Umbrella Thorn Forest, Southern Euphorbia Scrub Forest and Tropical Dry Evergreen Forest.

\section{Survey, sampling, data compilation and analysis}

Survey was conducted during 2013-2015 covering all aspects and different seasons. For the study of plant biodiversity, the division was divided based on 12 different forest types. These forest types were further separated depending on topography and altitude. Intensive field survey adopting $0.1 \%$ of the total area of each forest types was carried out following quadrat technique. For the quantitative assessment, a plot of $31.62 \times 31.62 \mathrm{~m}$ (65 nos.) quadrats were laid for trees, bamboos and lianas, and all the individuals were measured at GBH in the sample plots; quadrats of $5 \times 5 \mathrm{~m}$ (130 nos.) were established for shrubs, saplings and climbers and $1 \times 1 \mathrm{~m}$ (260 nos.) quadrats for herbs and seedlings. For the collection of data from these quadrats and analysis, standard ecological methods were followed (Domboise and Ellenberg, 1974). A species list of all the identified species was prepared with the help of flora guides and nearby area studied (Hooker, 1872-1897; Gamble and Fischer, 1915-1939; Henry et al., 1987; Henry et al., 1989; Matthew, 1981-1984; Ahmedulla and Nayar, 1987; Sanjappa, 1992; Nayar, 1996; Jagtap and Singh, 1999; Singh, 2002; Balakrishnan and Chakrabarty, 2007; Ansari, 2008; Tiwari and Ravikumar, 2018). Each sampled sites were marked with a Global Positioning System (GPS).

Quadrat data were used for computation of analytical features such as density, frequency, basal cover and important value index (IVI), following standard phytosociological methods as given by Curtis and McIntosh (1950). Diameter at breast height of the trees with $>20 \mathrm{~cm}$ circumference in each quadrat was measured and recorded for each species. The important value index (IVI) for the tree species was determined as the sum of the relative density, relative frequency and relative dominance (Curtis, 1959). The species diversity among forest types was determined by using Shannon Wiener information function $\left(\mathrm{H}^{\prime}\right)$ (Shannon and Wiener, 1963). Similarity index was demined by as per formula given by Sorenson (1948). For the calculation of dominance, the basal area was determined by using following formula:

Basal area $=\pi \mathrm{r} 2$

The index of diversity was computed by using Shannon Wiener Diversity Index (Shannon and Wiener, 1963) as:

$$
\mathrm{H}=-\Sigma(\mathrm{ni} / \mathrm{n}) \times \ln (\mathrm{ni} / \mathrm{n})
$$


Where, $\mathrm{H}$ is Shannon Wiener Diversity index; $\mathrm{S}$ is number of species.

The data on vegetation collected through quadrat study was quantitatively analysed for abundance, density and frequency. Species diversity and evenness index was calculated by using the Shannon-Wiener Diversity Index (1963) and Evenness Index, respectively.

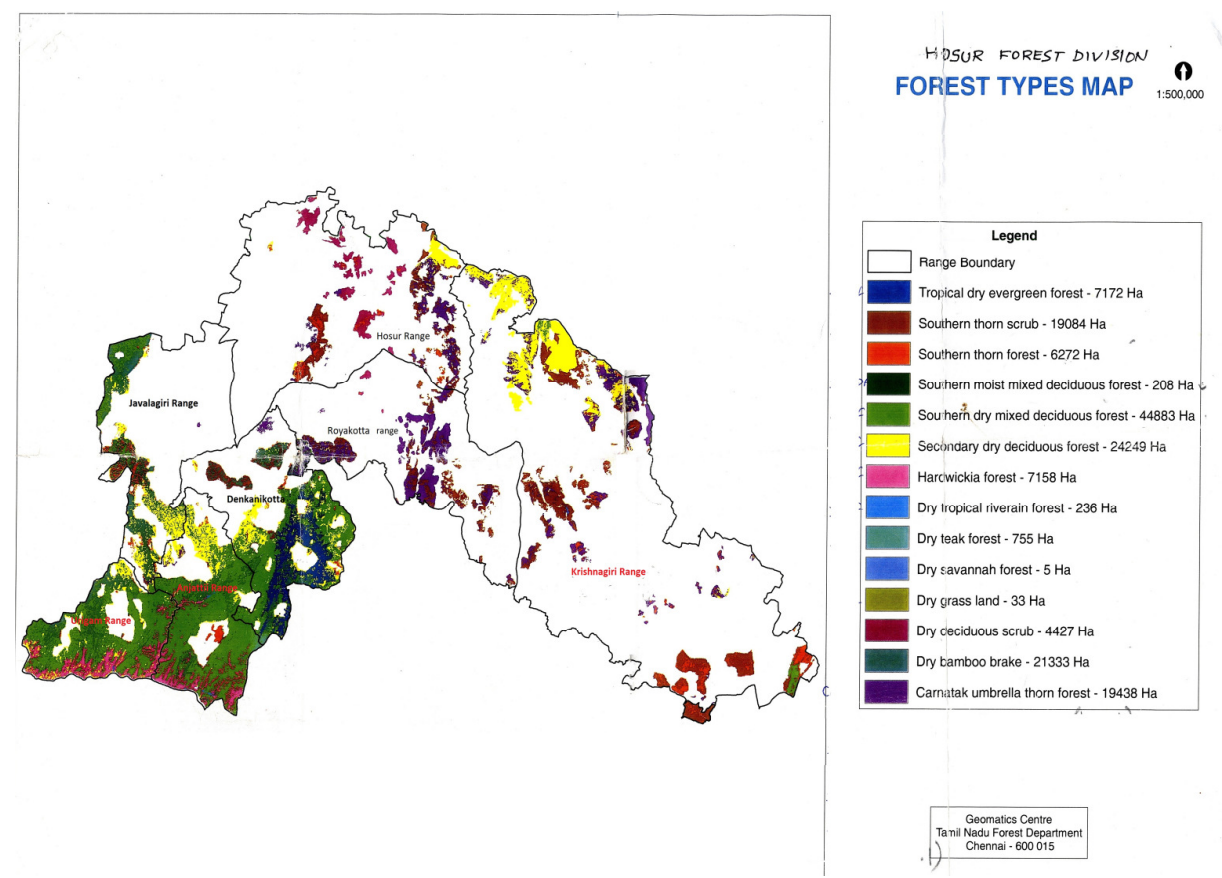

Fig. 1. Hosur Forest Division (Source: GIS cell Chennai, TNFD, Tamil Nadu)

\section{Results}

Floristic diversity and threatened status

The study recorded 468 species of plants, of 283 genera belonging to 91 families (Appendix-1) i.e. Angiosperms (464 species), Pteridophytes (3 species) and Bryophytes (1 species) (Table 1). Of the total species, 94 species were trees, 12 species were lianas, 70 species of shrubs, 34 species of climbers, 194 species of herbs, sedges 7 , grasses 21, ferns 3 species and 1 species of moss. Among these recorded species, based on Ravikumar and Ved (2000) (Appendix-1), one (01) species was labelled as Endangered; six (6) species as Vulnerable; one (01) species as Near Threatened; sixteen (16) species are Endemic to Southern India; and 01 Data deficient for the division.

Table 1. Floristic diversity in various forest types of Hosur Forest Division (HFD)

\begin{tabular}{|c|c|c|c|c|c|c|c|c|c|c|c|c|c|}
\hline Habits & CUTF & $\mathrm{DBB}$ & DDS & HwkF & $\mathrm{RvF}$ & SDDF & SDMDF & SDS & SMMD & STF & STS & TDEF & HFD \\
\hline Tree & 17 & 34 & 3 & 7 & 9 & 16 & 56 & 5 & 17 & 19 & 18 & 23 & 94 \\
\hline Liana & 8 & 6 & 2 & 1 & 0 & 1 & 7 & 2 & 1 & 5 & 4 & 1 & 12 \\
\hline Shrub & 19 & 21 & 17 & 10 & 4 & 31 & 42 & 9 & 11 & 28 & 31 & 22 & 70 \\
\hline Climber & 16 & 9 & 7 & 5 & 1 & 18 & 22 & 6 & 2 & 15 & 14 & 10 & 34 \\
\hline Herb & 60 & 30 & 38 & 23 & 7 & 56 & 11 & 13 & 24 & 93 & 81 & 23 & 194 \\
\hline Grass & 13 & 8 & 4 & 6 & 0 & 10 & 11 & 2 & 1 & 8 & 10 & 2 & 21 \\
\hline Sedges & 3 & 0 & 1 & 0 & 0 & 3 & 3 & 0 & 1 & 1 & 2 & 1 & 7 \\
\hline Fern & 1 & 2 & 0 & 0 & 0 & 0 & 2 & 0 & 0 & 0 & 1 & 0 & 3 \\
\hline Moss & 0 & 0 & 1 & 0 & 0 & 1 & 0 & 0 & 0 & 0 & 0 & 0 & 1 \\
\hline Total species & 141 & 111 & 78 & 62 & 24 & 137 & 272 & 38 & 55 & 178 & 167 & 85 & 468 \\
\hline Number Genera & 111 & 96 & 66 & 49 & 21 & 90 & 188 & 36 & 50 & 124 & 123 & 70 & 283 \\
\hline Number of Family & 48 & 40 & 34 & 24 & 18 & 45 & 72 & 27 & 31 & 55 & 53 & 39 & 91 \\
\hline EN & 0 & 1 & 0 & 0 & 0 & 0 & 0 & 0 & 0 & 0 & 0 & 0 & 1 \\
\hline Endemic (SI or PI) & 5 & 5 & 3 & 1 & 0 & 4 & 5 & 0 & 0 & 5 & 1 & 1 & 16 \\
\hline NT & 0 & 0 & 0 & 0 & 0 & 0 & 1 & 0 & 1 & 0 & 0 & 0 & 1 \\
\hline Least concern & 0 & 0 & 0 & 0 & 0 & 2 & 2 & 0 & 0 & 1 & 2 & 1 & 4 \\
\hline $\mathrm{Vu}$ & 1 & 2 & 0 & 1 & 0 & 2 & 3 & 0 & 2 & 3 & 2 & 2 & 6 \\
\hline DD & 0 & 0 & 0 & 0 & 0 & 0 & 0 & 0 & 0 & 0 & 0 & 1 & 1 \\
\hline
\end{tabular}

CUTF: Carnatic Umbrella Thorn Forest; DBB: Dry Bamboo Brake; DDS: Dry Deciduous Forest ; HwkF: Hardwickia Forest; RvF: Riverain Forest ; SDDF: Secondary Dry Deciduous Forest; SDMD: Southern Dry Mixed Deciduous; SDS: Southern Dry Scrub; SMMD: Southern Moist Mixed Deciduous Forest; STF: Southern Thorn Forest; STS: Southern Thorn Scrub; TDEF: Tropical Dry Evergreen Forest; HFD: Hosur Forest Division; EN: Endangered; SI or PI: Southern or Peninsular India; NT: Near Threatened; VL: Vulnerable. 
600

\section{Compositional features}

Southern tropical dry mixed deciduous forest

This is the most conspicuous type of deciduous forest in the division spreading over almost all the reserved forests of Anchetty, Urigam, Denkanikottai ranges. Sandal and Bamboo, the two economically most valuable species are found exclusively in this forest. The species forming the upper and lower canopy are almost deciduous. Some of the predominant trees that are found to occur in this forest type are: Anogeissus latifolia, Chloroxylon swietenia, Psydrax dicoccus, Albizia amara, Cassia fistula, Holoptelea integrifolia, Phyllanthus emblica, Premna tomentosa, Vitex altissima, Cassine glauca, Diospyros ferrea, Strychnos nuxvomica, Shorea roxburghii and Ficus spp. Shorea roxburghii though occurs profusely in this sub type, but only in patches. The most common climbers/liana/straggler in this forest were: Cissus quadrangularis, Cocculus hirsutus, Scutia myrtina, Cryptolepis grandiflora, Jasminum spp., etc. The common herbs here were Orthosiphon aristatus, Evolvulus alsinoides, Oplismenus compositus, etc.

Tree layer: in this forest type, Albizia amara had the highest density (63.31 ha ${ }^{-1}$ ) and IVI (56.76) was recorded; it was followed by Chloroxylon swietenia $\left(\mathrm{D}=27.8 \mathrm{ha}^{-1}\right.$ and IVI $=17.90)$ and $P$ sydrax dicoccos $\left(\mathrm{D}=18.34 \mathrm{ha}^{-1}\right.$ and IVI $=$ 16.53).

Sapling and seedlings: in sapling (of tree species), Albizia amara was dominant among all other species present in this forest type, followed by Psydrax dicoccus and Acacia pinnata.

Shrub layer: Lantana camara $\left(\mathrm{D}=2,875 \mathrm{ha}^{-1}, \mathrm{IVI}=\right.$ 21.16), Tarenna asiatica $\left(\mathrm{D}=2,037.5 \mathrm{ha}^{-1}, \mathrm{IVI}=14.35\right)$, Chromolaena odorata $\left(\mathrm{D}=1,462.5 \mathrm{ha}^{-1}, \mathrm{IVI}=11.09\right)$ and Clausena dentata $\left(\mathrm{D}=987.5 \mathrm{ha}^{-1}, \mathrm{IVI}=8.79\right)$ were noted. The highest frequency was recorded for Lantana camara ( $f$ $=59.38 \%)$, followed by Tarenna asiatica $(\mathrm{f}=25 \%)$. The frequency ranged between 3-60\%.

Herb layer: the density ranged from $6.63 / \mathrm{m}^{2}$ to $0.03 / \mathrm{m}^{2}$, whereas grasses exhibited $26.25 \%$ of each plots. Among grasses, Setaria pumila $\left(\mathrm{D}=4.88 / \mathrm{m}^{2}\right)$, Aristida setacea $(\mathrm{D}=$ $\left.1.53 / \mathrm{m}^{2}\right)$, Aristida adscensionis $\left(\mathrm{D}=0.59 / \mathrm{m}^{2}\right)$ were followed by Oplismenus composites $\left(\mathrm{D}=0.47 / \mathrm{m}^{2}\right)$. Evolvulus alsinoides exhibited the maximum density $\left(\mathrm{D}=8.63 / \mathrm{m}^{2}\right)$ and $\mathrm{f}=65.63 \%$, followed by Ageratum conyzoides $(\mathrm{D}=$ $5.08 / \mathrm{m}^{2}$ and $\left.\mathrm{f}=50 \%\right)$, Sida cordifolia $\left(\mathrm{D}=4.41 / \mathrm{m}^{2}\right.$ and $\mathrm{f}=$ $68.75 \%$ ) and Pavonia odorata ( $\mathrm{D}=3.52 / \mathrm{m}^{2}$ and $\mathrm{f}=$ 43.75\%). The highest frequency was recorded for Sida cordifolia $(68.75 \%)$ and lowest for many species with $1.56 \%$.

Hardwickia subtype: Under Dry Deciduous forest, this subtype was very distinct. This classification is based on the abundant presence of Hardwickia binata. This tree occurs gregariously and often occupies the slopes that drain into the Cauvery, Chinnar and Anaibiddahalla on the West and Hosur valley in the East. This forest type is dominated along Cauvery River in Urigam (Bernapalli, Mallahalli beats), Anchetty (Naframpalayam and Pudur beats) ranges. Since this species is of evergreen nature, it stands out conspicuously in this subtype. Some of the other associated species are: Grewia flavescens, Atlantia recemosa, Dichrostachys cinerea, Chloroxylon swietenia, Erythroxylum monogynum and Pterolobium hexapetalum.
Tree layer: in this forest type the climax species was Hardwickia binata with the highest density $\left(59.96 \mathrm{ha}^{-1}\right)$ and IVI (101.65), followed by Albizia amara (D = $34.71 \mathrm{ha}^{-1}$ and IVI $=67.65)$ and Chloroxylon swietenia $\left(\mathrm{D}=25.25 \mathrm{ha}^{-1}\right.$ and IVI $=36.63$ )

Sapling and seedlings: in sapling (of tree species) stage Hardwickia binata was dominant among all other species present in this forest type, followed by Atlantia recemosa and Chloroxylon swietenia.

Shrub layer: Solanum pubescens (D $=1,333.33 \mathrm{ha}^{-1}$, IVI $=35.15)$, Opuntia dillenii $\left(\mathrm{D}=1,333.33 \mathrm{ha}^{-1}, \mathrm{IVI}=46.16\right)$, Dichrostachys cinerea $\left(\mathrm{D}=1,266.67 \mathrm{ha}^{-1}, \mathrm{IVI}=44.39\right)$ and Jatropha gossypifolia $\left(\mathrm{D}=1,000 \mathrm{ha}^{-1}\right.$, IVI $=28.71$ ) were noted. The highest frequency was recorded for Solanum pubescens, Jatropha gossypifolia and Cardiospermum canescens $(\mathrm{f}=50 \%)$. The frequency ranged from $16-50 \%$.

Herb layer: the density ranged from $0.08 / \mathrm{m}^{2}$ to $12.50 / \mathrm{m}^{2}$, grasses exhibited $18 \%$ of each plot. Among grasses, Setaria pumila $\left(\mathrm{D}=2.9 / \mathrm{m}^{2}\right)$ and Aristida setacea (D $\left.=1.5 / \mathrm{m}^{2}\right)$ were more abudant. Sida cordifolia exhibited the maximum density $\left(\mathrm{D}=4.75 / \mathrm{m}^{2}\right)$ and $\mathrm{f}=66.67 \%$, followed by Evolvulus alsinoides $\left(\mathrm{D}=3.75 / \mathrm{m}^{2}\right.$ and $\left.\mathrm{f}=66.67 \%\right)$, Peristrophe bicalyculata $\left(\mathrm{D}=3.58 / \mathrm{m}^{2}\right.$ and $\left.\mathrm{f}=41.67 \%\right)$ and Spermacoce stricta ( $\mathrm{D}=3.00 / \mathrm{m}^{2}$ and $\left.\mathrm{f}=33.33 \%\right)$. The highest frequency was recorded for Sida cordifolia and Evolvulus alsinoides $(66.67 \%)$ and lowest for 17 species with $8.33 \%$.

Secondary Dry Deciduous Forest (SDDF): this forest type dominated in Krishnagiri (Veppanapalli, Naralapalli, Poonguruthi and Thattakal beats) and Anchetty (Panai east and Kondukottai beats) ranges. Basically, this is a mixed deciduous forest, but due to continuous exploitation and biotic interferences it is converted into secondary serial forest type. This forest was dominated by Albizia amara and other associate species such as: Pterolobium hexapetalum, Azadirachta indica, Annona squamosa, Euphorbia tortilis, Chloroxylon swietenia, Capparis zeylanica, Grewia flavescens, Ziziphus oenopolia, Grewia orientalis, Holoptelea integrifolia, Baubinia racemosa, Acalypha fruticosa, Tarenna asiatica, Cassia glauca, Grewia tenax, Dioscorea pentaphylla, Solanum pubescens, Gymnema sylvestre, Jasminum spp. Pachygone ovata, Gyrocarpus americanus, Cordia monoica, Fluggea leucopyrus, Ziziphus trinervia, Dichrostachys cinerea and Moringa concanensis etc. In this forest type the climax species was Albizia amara which had the highest density (167.71 ha' $\left.{ }^{-1}\right)$ and IVI (70.29), followed by Pterolobium hexapetalum ( $\mathrm{D}=25.70 \mathrm{ha}^{-1}$ and IVI $=14.36)$, Annona squamosa $\left(\mathrm{D}=22.99 \mathrm{ha}^{-1}\right.$ and IVI $=$ 6.08), Azadirachta indica ( $\mathrm{D}=21.64 \mathrm{ha}^{-1}$ and IVI $\left.=13.69\right)$ and Euphorbia tortilis ( $\mathrm{D}=21.64 \mathrm{ha}^{-1}$ and IVI $\left.=6.87\right)$.

Sapling and seedlings: in sapling (of tree species) Albizia amara and Acacia pinnata were dominant among all other species present in this forest type, followed by Chloroxylon swietenia and Azadirachta indica.

Shrub layer: Lantana camara $\left(\mathrm{D}=2,742.86 \mathrm{ha}^{-1}, \mathrm{IVI}=\right.$ 32.48), Solanum pubescens $\left(\mathrm{D}=1,771.43 \mathrm{ha}^{-1}, \mathrm{IVI}=23.77\right)$, Flueggea leucopyrus $\left(\mathrm{D}=1,371.43 \mathrm{ha}^{-1}\right.$, IVI $\left.=19.63\right)$, Catunaregam spinosa $\left(\mathrm{D}=1,228.57 \mathrm{ha}^{-1}, \mathrm{IVI}=18.29\right)$ and 
Opuntia dillenii $\left(\mathrm{D}=1,085.71 \mathrm{ha}^{-1}\right.$, IVI $\left.=16.53\right)$ were noted. The highest frequency was recorded for Lantana camara and Flueggea leucopyrus ( $\mathrm{f}=57.14 \%$ ) followed by Opuntia dillenii $(\mathrm{f}=50 \%$ ). The frequency ranged from 7.14-57.14\%.

Herb layer: the density ranged from $0.04 / \mathrm{m}^{2}$ to $8.79 / \mathrm{m}^{2}$, grasses exhibited $4 \%$ of each plot. Among the dominant species, there were Mitracarpus hirtus (D $=8.79 / \mathrm{m}^{2}$ ), Aristida adscensionis $\left(\mathrm{D}=5.25 / \mathrm{m}^{2}\right)$, Sida cordifolia $(\mathrm{D}=$ $\left.2.71 / \mathrm{m}^{2}\right)$, followed by Sida acuta $\left(\mathrm{D}=2.50 / \mathrm{m}^{2}\right)$. Sida cordifolia exhibited the maximum frequency of $46.43 \%$, followed by Aristida adscensionis ( $\mathrm{f}=42.86 \%$ ), Sida acuta and Spermacoce stricta $(\mathrm{f}=21.43 \%)$ and lowest frequency for 11 species with $3.57 \%$.

Dry Deciduous Scrub Forest (DDS): this forest type is common in Hosur (Kodasadhanpalli and Carubeler beats) range. Due to persistent felling and removal of useful species this forest type was subjected to a high degree of degradation over a prolonged period of time, by which all the tall trees eventually disappeared, resulting into stunted growth of few scattered trees seen in open forest. Some of the common species composition were Euphorbia antiquorum, Wrightia tinctoria, Albizia amara, Chloroxylon swietenia, Dichrostachys cinerea, Diospyros spp., Cipadessa baccifera, Ehretia pubescens, Atalantia monophylla, Annona squamosa, Butea monosperma, Feronia elephantum, Dodonaea viscosa, Catunaregum spinosa, Pavetta indica, Lantana camara, Ziziphus mauritiana, Gymnema sylvestre, Cassia montana, Azadirachta indica, Hemidesmus indicus, Ichnocarpus frutescsens, Secamone emetic, etc. In this forest type the climax species was Euphorbia antiquorum, with the highest density (99.40 ha ${ }^{-1}$ ) and IVI (137.54) recorded and was followed by Toddalia asiatica var. gracilis $\left(\mathrm{D}=56.80 \mathrm{ha}^{-1}\right.$ and IVI $=20.26)$, Wrightia tinctoria $\left(\mathrm{D}=47.3 \mathrm{ha}^{-1}\right.$ and IVI $=78.51)$, Albizia amara $\left(\mathrm{D}=14.2 \mathrm{ha}^{-1}\right.$ and $\left.\mathrm{IVI}=28.96\right)$ and Cassia fistula $\left(\mathrm{D}=4.7 \mathrm{ha}^{-1}\right.$ and IVI $\left.=20.25\right)$.

Sapling and seedlings: among sapling (of tree species) Diospyros montana was dominant among all other species present in this forest type, followed by Wrightia tinctoria, Ehretia pubescens and Flacourtia indica.

Shrub layer: Acalyph a fruticosa (D , = $2100 \mathrm{ha}^{-1}, \mathrm{f}=50 \%$, IVI $=29.56)$, Flueggea leucopyrus (D = 1,700 ha-1, $\mathrm{f}=75 \%$, IVI $=24.66)$, Cassia montana $\left(\mathrm{D}=1,500 \mathrm{ha}^{-1}, \mathrm{f}=75 \%\right.$, IVI $=22.69)$, Catunaregam spinosa $\left(\mathrm{D}=1,500 \mathrm{ha}^{-1}, \mathrm{f}=75 \%\right.$, IVI $=22.69)$, Lantana camara (D $=1,400 \mathrm{ha}^{-1}, \mathrm{f}=25 \%$, IVI = 26), Dodonaea viscosa $\left(\mathrm{D}=1,000 \mathrm{ha}^{-1}, \mathrm{f}=50 \%\right.$, IVI $=$ 16.83). The lowest density, frequency and IVI were recorded for Coccinia grandis and Ziziphus oenoplia (D = $\left.100 \mathrm{ha}^{-1}, \mathrm{f}=25 \%, \mathrm{IVI}=4.30\right)$. The frequency ranged from $25-75 \%$.

Herb layer: the density ranged from $0.25 / \mathrm{m}^{2}$ to $17.75 /$ $\mathrm{m}^{2}$, grasses exhibited $10 \%$ of each plot. Spermacoce articularis $\left(\mathrm{D}=17.75 / \mathrm{m}^{2}, \mathrm{f}=37.5 \%\right)$, Spermacoce ocymoides $\left(\mathrm{D}=15 / \mathrm{m}^{2}, \mathrm{f}=25 \%\right)$, Cyanotis tuberosa $\left(\mathrm{D}=6.13 / \mathrm{m}^{2}, \mathrm{f}=\right.$ $87.5 \%)$ Brachiaria distachya $\left(\mathrm{D}=4.38 / \mathrm{m}^{2}, \mathrm{f}=12.5 \%\right)$, Oropetium thomaeum ( $\left.\mathrm{D}=4.38 / \mathrm{m}^{2}, \mathrm{f}=25 \%\right)$, were ollowed by Glossocardia bosvallia $\left(\mathrm{D}=3.57 / \mathrm{m}^{2}, \mathrm{f}=12.5 \%\right)$.

Dry Tropical Riverain forests: This forest type was particularly noticeable along Cauvery River in Urigam and in Anchetty (Bilikundull beat) ranges. The most principal and unique tree species of this type was Terminalia arjuna mixed with Syzygium cumini, Pongamia pinnata, Madhuca longifolia, Barringtonia acutangula. Other life forms such as Crinum asiaticum, Homonaia retusa, Benkara malabarica, Catenorum parvifolia and Cyperus sp. and Citrullus colocynthis were also seen in this forest type. In this forest type the climax species was Syzygium cumini with the highest density (75.74 $\mathrm{ha}^{-1}$ ) and IVI (43.05) recorded, followed by Barringtonia acutangula (D $=66.27 \mathrm{ha}^{-1}$ and IVI $=54.94)$, Terminalia arjuna $\left(\mathrm{D}=56.8 \mathrm{ha}^{-1}\right.$ and IVI $=$ 25.11), Pongamia glabra (D $=37.87 \mathrm{ha}^{-1}$ and IVI $\left.=30.04\right)$ and Madhuca longifolia ( $\mathrm{D}=9.46 \mathrm{ha}^{-1}$ and IVI $\left.=77.98\right)$.

Sapling and seedlings: in sapling (of tree species) stage Pongamia glabra was dominant among all other species present in this forest type, followed by Barringtonia acutangula, Syzygium cumini and Terminalia arjuna.

Shrub layer: Homonoia retusa (D $=3,400 \mathrm{ha}^{-1}, \mathrm{f}=100 \%$, IVI $=134.45)$, Catenorum parvifolia $\left(\mathrm{D}=1,200 \mathrm{ha}^{-1}, \mathrm{f}=\right.$ $100 \%$, IVI $=61.83)$, Alangium salvifolium $\left(\mathrm{D}=200 \mathrm{ha}^{-1}, \mathrm{f}\right.$ $=50 \%$, IVI $=20.74)$, Benkara malabarica $\left(\mathrm{D}=200 \mathrm{ha}^{-1}, \mathrm{f}=\right.$ $50 \%, \mathrm{IVI}=20.74)$ and Cassine glauca $\left(\mathrm{D}=200 \mathrm{ha}^{-1}, \mathrm{f}=\right.$ $50 \%$, IVI $=20.74$ ).

Herb layer: the density ranged from $0.25 / \mathrm{m}^{2}$ to $5.75 /$ $\mathrm{m}^{2}$. Maximum density was recorded for Crinum arisatica (D $\left.=5.75 / \mathrm{m}^{2}, \mathrm{f}=25 \%\right)$, Crotalaria paniculata $\left(\mathrm{D}=0.5 / \mathrm{m}^{2}, \mathrm{f}=\right.$ 25\%), Citrullus colocynthis, Crotalaria sedicagenes, Merremia tridentata, Mimosa pudica and Phyllanthus simplex (D = $\left.0.25 / \mathrm{m}^{2}, \mathrm{f}=25 \%\right)$.

Southern Thorn Forests (STF): This type of forest occurs mostly in the southern-eastern part of the division covering entire Jawalagiri, Roykottai and Krishnagiri ranges. Floristically it is dominated by Albizia amara, Euphorbia antiquorum, Pterolobium hexapetalum, Wrightia tinctoria, Ziziphus oenopolia, Cassia siamea, Azadirachta indica, Acacia chundra, Maytenus emarginatus, Acacia spp., Scutia myrtina, Ziziphus xylopyrus, Capparis zeylanica, Catunaregam spinosa, Ipomoea staphylina, Hemidesmus indicus, Commiphora berryi and Azadirachta indica. This forest type was dominated by Albizia amara (D $=56.80$ ha $^{-}$ ${ }^{1}, \mathrm{f}=60 \%$, IVI = 35.44), followed by Euphorbia antiquorum $\left(\mathrm{D}=35.98 \mathrm{ha}^{-1}, \mathrm{f}=60 \%\right.$, IVI $\left.=19.39\right)$, Pterolobium hexapetalum ( $\mathrm{D}=32.19 \mathrm{ha}^{-1}, \mathrm{f}=60 \%$, IVI $\left.=14.57\right)$, Wrightia tinctoria $\left(\mathrm{D}=30.30 \mathrm{ha}^{-1}, \mathrm{f}=40 \%\right.$, IVI $\left.=10.28\right)$, Ziziphus oenopolia ( $\mathrm{D}=28.4 \mathrm{ha}^{-1}, \mathrm{f}=60 \%$, IVI $\left.=15.23\right)$, Cassia siamea ( $\left.\mathrm{D}=13.25 \mathrm{ha}^{-1}, \mathrm{f}=20 \%, \mathrm{IVI}=6.99\right)$ and Azadirachta indica (D $\left.=11.36 \mathrm{ha}^{-1}, \mathrm{f}=40 \%, \mathrm{IVI}=6.88\right)$.

Sapling and seedlings: in sapling (of tree species) Albizia amara was dominant among all other species present in this forest type, followed by Pterolobium hexapetalum, Wrightia tinctoria and Azadirachta indica.

Shrub layer: Lantana camara (D = 4,240 ha- ${ }^{-1}, f=90 \%$, IVI $=29.11)$, Dodonaea viscosa $\left(\mathrm{D}=1,760 \mathrm{ha}^{-1}, \mathrm{f}=30 \%\right.$, IVI $=15.31)$, Flueggea leucopyrus $\left(\mathrm{D}=1,560 \mathrm{ha}^{-1}, \mathrm{f}=60 \%\right.$, IVI $=13.65)$, Flacourtia indica $\left(\mathrm{D}=1,520 \mathrm{ha}^{-1}, \mathrm{f}=20 \%\right.$, IVI $=15.23)$ and Catunaregam spinosa $\left(\mathrm{D}=1,160 \mathrm{ha}^{-1}, \mathrm{f}=\right.$ $50 \%$, IVI $=10.95)$. Eleven (11) species had the lowest density, frequency and IVI $\left(\mathrm{D}=40 \mathrm{ha}^{-1}, \mathrm{f}=10 \%, \mathrm{IVI}=\right.$ 1.34). The frequency ranged from $10-90 \%$. 
602

Herb layer: the density ranged from $0.05 / \mathrm{m}^{2}$ to $15.60 / \mathrm{m}^{2}$, dominant species were Sida cordifolia $(\mathrm{D}=$ $\left.15.60 / \mathrm{m}^{2}, \mathrm{f}=35 \%\right)$, Spermacoce ocymoides $\left(\mathrm{D}=4.45 / \mathrm{m}^{2}, \mathrm{f}\right.$ $=20 \%)$, Alloteropsis cimicina $\left(\mathrm{D}=3.85 \mathrm{~m}^{2}, \mathrm{f}=15 \%\right)$, Oropetium thomaeum (D $\left.=3.80 / \mathrm{m}^{2}, \mathrm{f}=20 \%\right)$, Evolvulus alsinoides ( $\left.\mathrm{D}=3.45 / \mathrm{m}^{2}, \mathrm{f}=50 \%\right)$, followed by Glossocardia bosvallia $\left(\mathrm{D}=3.40 \mathrm{~m}^{2}, \mathrm{f}=20 \%\right)$.

Southern Thorn Scrub (STS): when the thorn forests are repeatedly hacked at higher intensity these forests are reduced to a mere scrub land consisting of thorny bushes and stunted tree growth averaging 2-3 meters in height. Impenetrable thorny thickets are also commonly met within this type of forests. This forest is usually represented by species like Albizia amara, Chloroxylon swietenia, Azadirachta indica, Psydrax dicoccus, Toddalia asiatica var. gracilis, Pterolobium bexapetalum, Erythroxylon monogynum, Dodonaea viscosa, Acacia caesia, Acacia chundra, Acacia ferruginea, Ziziphus xylopyrus, Dichrostachys cinerea, Lantana camera and Caralluma adscendens var. attenuata. This forest type is dominated by Albizia amara $\left(\mathrm{D}=66.27 \mathrm{ha}^{-1}, \mathrm{f}=66.67 \%\right.$, IVI $\left.=71.16\right)$, followed by Acacia chundra (D = $34.71 \mathrm{ha}^{-1}, \mathrm{f}=16.67 \%$, IVI $\left.=20.77\right)$, Azadirachta indica (D $=34.71 \mathrm{ha}^{-1}, \mathrm{f}=83.33 \%$, IVI = 32.85), Canthium coromandelicum ( $\mathrm{D}=20.51 \mathrm{ha}^{-1}, \mathrm{f}=$ 16.67\%, IVI $=12.69)$ and Pterolobium hexapetalum (D = $14.20 \mathrm{ha}^{-1}, \mathrm{f}=50 \%$, IVI = 14.14), Annona squamosa $(\mathrm{D}=$ $12.62 \mathrm{ha}^{-1}, \mathrm{f}=33.33 \%$, IVI $\left.=10.10\right)$ and Chloroxylon swietenia $\left(\mathrm{D}=12.62 \mathrm{ha}^{-1}, \mathrm{f}=16.67 \%\right.$, IVI $\left.=7.94\right)$.

Sapling and seedlings: in sapling (of tree species) Chloroxylon swietenia, Canthium coromandelicum, Acacia chundra were dominant among all other species present in this forest type, followed by Pterolobium hexapetalum, Albizia amara, Grewia orientalis, Sarcostemma acidum, Phoenix pusilla and Derris scandens.

Shrub layer: Lantana camara $\left(\mathrm{D}=4,033.33 \mathrm{ha}^{-1}, \mathrm{f}=\right.$ $83.33 \%$, IVI $=27.79)$, Dodonaea viscosa $\left(\mathrm{D}=3,133.33 \mathrm{ha}^{-1}\right.$, $\mathrm{f}=50 \%$, IVI = 21.76), Acacia leucophloea $(\mathrm{D}=2,833.33$ ha $1, \mathrm{f}=8.33 \%$, IVI = 35.01), Catunaregam spinosa (D = $1,766.67 \mathrm{ha}^{-1}, \mathrm{f}=66.67 \%$, IVI $\left.=15.65\right)$, Flueggea leucopyrus $\left(\mathrm{D}=1,333.33 \mathrm{ha}^{-1}, \mathrm{f}=58.33 \%, \mathrm{IVI}=12.84\right)$ and Cassia montana $\left(\mathrm{D}=1,100 \mathrm{ha}^{-1}, \mathrm{f}=16.67 \%\right.$, IVI $\left.=10.52\right)$. Seventeen (17) species were recorded with lowe density, frequency and IVI for the forest type. The frequency ranged between 8.33-83.33\%.

Herb layer: the density ranged from $1.5 / \mathrm{m}^{2}$ to $47.25 /$ $\mathrm{m}^{2}$, grasses exhibited $15 \%$ of each plots. Maximum density was recorded for Cymbopogon flexuosus $\left(\mathrm{D}=47.25 / \mathrm{m}^{2}, \mathrm{f}=\right.$ $100 \%)$, Tephrosia tinctoria $\left(\mathrm{D}=24.5 / \mathrm{m}^{2}, \mathrm{f}=75 \%\right)$, Alloteropsis cimicina $\left(\mathrm{D}=20.5 / \mathrm{m}^{2}, \mathrm{f}=75 \%\right)$, Evolvulus alsinoides $\left(\mathrm{D}=6 / \mathrm{m}^{2}, \mathrm{f}=50 \%\right)$, Justicia tranquebariensis (D $\left.=4.75 / \mathrm{m}^{2}, \mathrm{f}=75 \%\right)$, followed by Ageratum conyzoides $(\mathrm{D}=$ $\left.4.75 / \mathrm{m}^{2}, \mathrm{f}=50 \%\right)$.

Carnatic Umbrella Thorn Forest (CUTF): this forest type is very common in Royakottai, Denkanikottam and Krishnagiri ranges. Vegetation is of open thorny forests with scattered Acacia planifrons and Albizia amara that are characterized by umbrella-shaped crowns. Other floristic elements seen in this forest type are: Acalypha fruticosa, Holoptelea integrifolia, Dodonaea viscosa, Solanum pubescens,
Cocculus birsutus, Cissus quadrangularis, Cryptolepis grandiflora, Abutilon crispum, Sarcostemma acidum, Sida spp., Dioscorea spp., Corallocarpus epigaeus, Cardiospermum canescens, Barleia longiflora, Gymnema sylvestre, etc. In CUTF forest a total of 141 species were recorded.

Tree layer: in this forest type 17 tree species and 8 lianas were recorded; the dominating species in this forest were Acacia planifrons (D $\left.=160.95 \mathrm{ha}^{-1}, \mathrm{f}=100 \%, \mathrm{IVI}=112\right)$, Albizia amara (D $=40.57 \mathrm{ha}^{-1}, \mathrm{f}=85.71 \%$, IVI $\left.=31\right)$, Azadirachta indica (D $=21.64 \mathrm{ha}^{-1}, \mathrm{f}=42.86 \%$, IVI $=$ 15.8), Pterolobium hexapetalum ( $\mathrm{D}=20.29 \mathrm{ha}^{-1}, \mathrm{f}=$ 42.86\%, IVI = 12.8), Annona squamosa $\left(\mathrm{D}=18.93 \mathrm{ha}^{-1}, \mathrm{f}=\right.$ $42.86 \%$, IVI $=12.8)$, Euphorbia antiquorum (D $=17.58$ ha $\left.{ }^{1}, \mathrm{f}=42.86 \%, \mathrm{IVI}=14.4\right)$, Euphorbia tortilis $\left(\mathrm{D}=13.52 \mathrm{ha}^{-}\right.$ ${ }^{1}, \mathrm{f}=14.29 \%$, IVI $\left.=10.7\right)$, Diospyros montana $(\mathrm{D}=10.82$ $\left.\mathrm{ha}^{-1}, \mathrm{f}=14.29 \%, \mathrm{IVI}=6.29\right)$ and Wrightia tinctoria $(\mathrm{D}=$ $8.11 \mathrm{ha}^{-1}, \mathrm{f}=28.57 \%$, IVI $=6.8$ ).

Shrub layer: in this forest type, 19 species of shrubs and 16 species of climbers were recorded, among these dominant species were Acalypha fruticosa (D =8,000 ha ${ }^{-1}, \mathrm{f}$ $=50 \%, \mathrm{IVI}=56.62)$, Lantana camera $\left(\mathrm{D}=6,314.29 \mathrm{ha}^{-1}, \mathrm{f}\right.$ $=57.14 \%$, IVI $=45.37)$, Solanum pubescens $(\mathrm{D}=1,885.71$ $\mathrm{ha}^{-1}, \mathrm{f}=35.71 \%$, IVI = 18.20), Flueggea leucopyrus (D = $1,828.57 \mathrm{ha}^{-1}, \mathrm{f}=64.29 \%$, IVI $\left.=19.18\right)$, Gymnema sylvestre $\left(\mathrm{D}=1,040 \mathrm{ha}^{-1}, \mathrm{f}=40 \%, \mathrm{IVI}=12.7\right)$, Tarenna asiatica $(\mathrm{D}$ $=880 \mathrm{ha}^{-1}$, $\mathrm{f}=26.67 \%$, IVI $\left.=10.5\right)$, Jasminum angustifolium and Jatropha gossypiifolia $\left(\mathrm{D}=600 \mathrm{ha}^{-1}, \mathrm{f}=\right.$ $21.43 \%$, IVI $=8.36$ ).

Herb layer: among herbaceous species, grasses were dominant in ground cover in this forest type. Were noted Sida acuta $\left(\mathrm{D}=3.36 \mathrm{ha}^{-1}, \mathrm{f}=17.86 \%\right)$, Digitaria bicornis $(\mathrm{D}$ $\left.=3.07 \mathrm{ha}^{-1}, \mathrm{f}=1071 \%\right)$, Evolvulus alsinoides $\left(\mathrm{D}=2.93 \mathrm{ha}^{-1}\right.$, $\mathrm{f}=28.57 \%)$, Digitaria ciliaris $\left(\mathrm{D}=2.14 \mathrm{ha}^{-1}, \mathrm{f}=10.71 \%\right)$, Sida cordifolia $\left(\mathrm{D}=28.57 \mathrm{ha}^{-1}, \mathrm{f}=7.5 \%\right)$, Kyllinga monocephala $\left(\mathrm{D}=2.11 \mathrm{ha}^{-1}, \mathrm{f}=17.86 \%\right)$, Cynotis cristata (D $\left.=1.96 \mathrm{ha}^{-1}, \mathrm{f}=14.29 \%\right)$, Ocimum americanum $(\mathrm{D}=1.96$ $\left.\mathrm{ha}^{-1}, \mathrm{f}=25 \%\right)$, Blepharis repens $\left(\mathrm{D}=1.75 \mathrm{ha}^{-1}, \mathrm{f}=17.86 \%\right)$ and Dipteracanthus prostratus ( $\left.\mathrm{D}=1.68 \mathrm{ha}^{-1}, \mathrm{f}=25 \%\right)$.

Southern Euphorbia Scrub (SES): this is an extremely degraded type of forest, seen in pockets along the fringes of the Carnatic umbrella Thorn Forests. No noteworthy tree growths are seen here. The vegetation comprises mostly of Euphorbia antiquorum, Euphorbia tortilis with Albizia amara, Azadirachta indica and Annona squamosa. Some of the worthy species to be mentioned in this forest type are: Coccinea indica, Caralluma spp., Rhynchosia minima, Sida spp., Commiphora berryi, Dioscorea spp., Cardiospermum halicacabum, Barleria buxifolia, etc.

Southern Dry Scrub (SDS): this is an also extremely degraded type of forest and was seen in few pockets in the division. Some of the plants found in this forest type were Albizia amara, Azadirachta indica, Pterolobium hexapetalum, Holoptelea integrifolia, Celastrus paniculatus, Strychnos nux-vomica, Wrightia tinctoria, Cassia montana, Cassia auriculata, Gymnema sylvestre, Cryptolepis grandiflora, Annona squamosa, Lantana camara, Cissus quadrangularis, Cymbopogon flexuosus, Tephrosia tinctoria, Alloteropsis cimicina, Evolvulus alsinoides, Justicia tranquebariensis, Ageratum conyzoides, Aristida setacea, 
Corchorus aestuans, Pavonia odorata, Mitracarpus hirtus, Apluda mutica and Cyanotis tuberosa etc.

Dry Bamboo Brake (DBB): both the species of bamboos viz. Bambusa bambos and Dendrocalamus strictus occur in this division almost in equal extent and sometimes both species were found mixed in the same locality. Some of the other associated trees found in this type were: Pterocarpus marsupium, Dalbergia lanceolaria, Cassia fistula, Holoptelea integrifolia, Cassine glauca, etc. Some of the economically important species like Embelia tjerium-cottam and Asparagus racemosus were also found in Ayur RF.

Southern Moist Mixed Deciduous Forest (SMMD): this forest type is found at little higher elevation in Denkanikottam range. The vegetation is characterized by Strychnos potatorum, Erythroxylum monogynum, Canthium sp., Memecylon kollimalayana, Buchanania axillaris, Ochna obtusata var. gamblei, Acacia pennata, Cassine glauca, Ixora pavetta, Phyllanthus indofischeri, Pterolobium hexapetalum, Vitex altissima, Acalypha alnifolia, Chromolaena odorata, Flacourtia indica, Ixora arborea, Cajanus scarabaeoides, Argyreia cuneata, Erythroxylum monogynum, Decaschistia crotonifolia, Desmodium pulchellum, Gardenia gummifera, Curculigo orchioides, Cyanotis tuberosa, Crotalaria medicaginea, Mariscus dubius, Vernonia cinerea, Byttneria herbacea, Galactia tenuiflora, Andrographis serpyllifolia, Spermacoce articularis, Allmania nodiflora, Tephrosia tinctoria, Phyllanthus virgatus, Vernonia albicans, Chamaecrista pumila, Euphorbia cristata etc.

Tropical Dry Evergreen Forest (TDEF): these forests occupy limited extent in patches in sheltered pockets and folds of Melagiri hill near Gutrayan of Denkanikottam forest range. The vegetation is characterized by Mamecylon edule, Manilkara hexandra, Eugenia alternifolia, Syzygium gardneri, Litsea wightiana, Diospyros montana, Alseodaphne semecarpifolia, Pleurostylia wightii, Alphonsea sclerocarpa, Artabotrys odoratissima, Syzygium cumini, Memecylon kollimalayanum, Benkara malabarica, Anogeissus latifolia, Phyllanthus polyphyllus, Garcinia gummi-gutta, Dioscorea ovalifolia, Psydrax dicoccos, Miliusa montana, Chionanthus mala-elengi, Mangifera indica, Alseodaphne semecarpifolia, Canthium coromandelicum, Vitex altissima, Bambusa Table 2. Species diversity in different forest types of HFD

\begin{tabular}{cccccccccccccccc}
\hline & CUTF & DBB & DDS & HwkF & RvF & SDDF & SDMDF & SDS & SMMD & STF & STS & TDEF \\
\hline Taxa_S & 141 & 111 & 78 & 62 & 24 & 137 & 272 & 38 & 55 & 178 & 167 & 85 \\
Dominance_D & 0.01 & 0.01 & 0.01 & 0.02 & 0.04 & 0.01 & 0.00 & 0.03 & 0.02 & 0.01 & 0.01 & 0.01 \\
Simpson_1-D & 0.99 & 0.99 & 0.99 & 0.98 & 0.96 & 0.99 & 1.00 & 0.97 & 0.98 & 0.99 & 0.99 & 0.99 \\
Shannon_H & 4.95 & 4.71 & 4.36 & 4.13 & 3.18 & 4.92 & 5.61 & 3.64 & 4.01 & 5.18 & 5.12 & 4.44 \\
\hline
\end{tabular}

Table 3. Similarities percentage (\%) among different forest types

\begin{tabular}{|c|c|c|c|c|c|c|c|c|c|c|c|c|}
\hline & CUTF & DBB & DDS & HwkF & $\mathrm{RvF}$ & SDDF & SDMDF & SDS & SMMD & STF & STS & TDEF \\
\hline CUTF & 0 & 18 & 33 & 15 & 4 & 32 & 28 & 14 & 7 & 32 & 32 & 15 \\
\hline DBB & 18 & 0 & 13 & 23 & 5 & 23 & 22 & 10 & 11 & 19 & 18 & 19 \\
\hline DDS & 33 & 13 & 0 & 11 & 3 & 21 & 18 & 17 & 9 & 24 & 23 & 12 \\
\hline HwkF & 15 & 23 & 11 & 0 & 2 & 17 & 13 & 11 & 6 & 14 & 14 & 11 \\
\hline $\mathrm{RvF}$ & 4 & 5 & 3 & 2 & 0 & 5 & 4 & 5 & 7 & 5 & 5 & 6 \\
\hline SDDF & 32 & 23 & 21 & 17 & 5 & 0 & 27 & 18 & 9 & 32 & 34 & 15 \\
\hline SDMDF & 28 & 22 & 18 & 13 & 4 & 27 & 0 & 10 & 13 & 28 & 18 & 19 \\
\hline SDS & 14 & 10 & 17 & 11 & 5 & 18 & 10 & 0 & 9 & 15 & 15 & 10 \\
\hline SMMD & 7 & 11 & 9 & 6 & 7 & 9 & 13 & 9 & 0 & 10 & 10 & 32 \\
\hline STF & 32 & 19 & 24 & 14 & 5 & 32 & 28 & 15 & 10 & 0 & 38 & 13 \\
\hline STS & 32 & 18 & 23 & 14 & 5 & 34 & 18 & 15 & 10 & 38 & 0 & 51 \\
\hline TDEF & 15 & 19 & 12 & 11 & 6 & 15 & 19 & 10 & 32 & 13 & 51 & 0 \\
\hline
\end{tabular}


604

Table 4. Number of species common among different forest types

\begin{tabular}{ccccccccccccc}
\hline & CUTF & DBB & DDS & HwkF & RvF & SDDF & SDMDF & SDS & SMMD & STF & STS & TDEF \\
\hline CUTF & 0 & 213 & 165 & 172 & 159 & 202 & 311 & 156 & 182 & 231 & 222 & 197 \\
DBB & 213 & 0 & 167 & 141 & 128 & 201 & 362 & 142 & 157 & 264 & 255 & 165 \\
DDS & 165 & 167 & 0 & 125 & 99 & 195 & 322 & 107 & 128 & 229 & 220 & 146 \\
HwkF & 172 & 141 & 125 & 0 & 84 & 183 & 313 & 95 & 114 & 224 & 214 & 133 \\
RvF & 159 & 128 & 99 & 84 & 0 & 157 & 290 & 61 & 77 & 198 & 186 & 103 \\
SDDF & 202 & 201 & 195 & 183 & 157 & 0 & 361 & 161 & 184 & 272 & 260 & 193 \\
SDMDF & 311 & 362 & 322 & 313 & 290 & 361 & 0 & 296 & 308 & 393 & 385 & 299 \\
SDS & 156 & 142 & 107 & 95 & 61 & 161 & 296 & 0 & 89 & 201 & 191 & 112 \\
SMMD & 182 & 154 & 128 & 114 & 77 & 184 & 308 & 89 & 0 & 222 & 212 & 106 \\
STF & 231 & 264 & 229 & 224 & 198 & 272 & 393 & 201 & 222 & 0 & 291 & 232 \\
STS & 222 & 255 & 220 & 214 & 186 & 260 & 385 & 191 & 212 & 291 & 0 & 167 \\
TDEF & 197 & 165 & 146 & 133 & 103 & 208 & 328 & 118 & 131 & 246 & 237 & 0
\end{tabular}

CUTF: Carnatic Umbrella Thorn Forest; DBB: Dry Bamboo Brake; DDS: Dry Deciduous Forest; HwkF: Hardwickia Forest; RvF: Riverain Forest; SDDF: Secondary Dry Deciduous Forest; SDMD: Southern Dry Mixed Deciduous; SDS: Southern Dry Scrub; SMMD: Southern Moist Mixed Deciduous Forest; STF: Southern Thorn Forest; STS: Southern Thorn Scrub; TDEF: Tropical Dry Evergreen Forest.

\section{Native, rarity and endemic species}

As per the data collected and literature surveyed it was found that sixteen (16) species are endemic to peninsular India and twenty three (23) species were recorded as rare for Peninsular India, all recorded within Hosur Forest Division (HFD). Among threatened and near threatened category, one (01) species are endangered (EN) and six (6) species are vulnerable in the HFD. SDMD forest represents maximum numbers (11 nos.) of threatened species viz. endemic, endangered, rare and vulnerable followed by STS (05 nos.) (Table 1). Other forest types signify less number of threatened species.

\section{Discussion}

The biodiversity on earth provides a large number of services to humankind. Biodiversity not only helps in the regulation of soil and water, but it also provides food and shelter for survival of a large number of species. Increase in human population has resulted in demand of more and more biological resources (Daily, 1995; Singh, 2002). In the last 20 decades it has been observed that biological diversity is rigorously vulnerable by anthropogenic disturbances, whereas most of the rural people in India are fully dependent on forest products such as timber, livestock grazing, fuel wood consumption and fodder. An affluent species richness habitat is mainly governed by some of the environmental factors, which always influence the composition of that place. If anthropogenic disturbance is more than the richness of that habitat, the biodiversity will always be less, whereas less human intervention in any kind of habitat will contain good type of diversity.

The resources of any ecosystem are limited and for the sustainable exploitation of these resources we have to formulate some strategies. Such activities are impairing and destroying the ecosystems. For the conservation and management of these species in wild an attempt has been made to assess and identify the status of diversity in junction of Eastern and Western Ghats. During the survey period it has been observed that most of the areas were under tremendous pressure due to high percentage of livestock grazing and collection of fuel wood. The growth in human population over the years had both the positive and negative impact on the overall quality of the environment. As the demand for energy has increased, the potential for electrical energy production has also been tapped to a great extent. The assessment was done by using quantitative and qualitative attributes.

If we compare tree species richness among nearby forested area such as Bannerghatta forest with 41 tree species (Verma et al., 2009; Gopalakrishna et al., 2015), Mudumalai with 63 tree species (Condit et al., 2000), Dharmapuri FD with 51 tree species (Tiwari and Ravikumar, 2018), was noted in the present study for HFD there were 94 tree species, which is the highest number among the nearby forested area. The five most abundant families in HFD were Fabaceae ( 45 nos.), Poaceae (34 nos.), Acanthaceae (30 nos.), Euphorbiaceae (28 nos.) and Rubiaceae (25 nos.), while Tiwari and Ravikumar (2018) found Fabaceae and Acanthaceae to be most dominant families in Dharmapuri Forest Division, which is an adjutant forest division; Panda et al. (2013) had recorded Euphorbiaceae and Moraceae to be the most dominant families in northen portion of Eastern Ghats, while the southern portion of Eastern Ghats in Bannerghatta forest is dominated by families Fabaceae, Caesalpiniaceae and Rubuaceae (Gopalkrishna et al., 2015; Puttookame et al., 2015). Mimosaceae, Rubiaceae, Apocynaceae were the most dominant families in Piranmalai Forest (Pitchairamu et al., 2008), whereas Euphorbiaceae and Rubiaceae were most dominant in Shervarayan hill (Kadavul and Parthasarthy, 1999).

It is a well-known fact that forests provide the basic life support system to all living entities of earth including mankind. These ecosystems provide fresh air, water resources, fertile soil and agriculture, bio-diversity and environment, and in country like India vast sections of rural society, including a majority of the tribes, are directly dependent on forests for their livelihood. If these forests degrade it will have a serious adverse impact on these life sustaining systems. Forests are increasingly considered as a natural resource, from which communities will derive ecological services rather than economic returns. In sight of this thought, the floristic diversity of Hosur forests will help forest department to develop management plans for these tropical dry forests of Eastern Ghats. The quantitative biodiversity data of Eastern Ghats will be useful in forest 
management and conservation.

During the study period it was observed that all forested area of this division was subjected to continuous biotic pressure, resulting into rapid degradation. With the help of JFM concept these areas can slowly be restored for recouping the vegetation. Due to perpetual grazing as observed in many areas, the new seedlings and saplings of important species like bamboo, medicinal plants and other NTFP species are often subjected to continuous damage. Management of grazing is very important for the conservation of natural vegetation. This will help to increase in availability of biomass for fodder, fuelwood in forest areas.

In-situ conservation of plant or animal species uses diversified genetic resources in its natural condition. Both in-situ and ex-situ conservation are suitable for protecting the endangered species that are distributed across varied ecological conditions. To undertake these conservation programs effectively and efficiently some of the important methods that could be taken up are: (1) conduct the representative sampling for the populations of CR/EN/VL species; (2) collection and maintenance for seedlings/propagules/seeds of CR/EN/VL species; (3) utilization for in-situ actions will be used as a tool for efficiently solving specific conservation problems.

\section{Conclusions}

In analysis of the present study, it is shown the tree density in forests along with the rare and endemic species of the forest division. As far as CR/EN/DD taxa concerned, only few individuals (3 Nos.) of Decalepis hamiltonii were noticed in one plot. A good population of Memecylon bremeri, an endemic species to Tamil Nadum was recorded in the study area. With the help of such studies it has been identified the specific localities of each CR/EN/VL species for this division and these localities can be further monitored to know their population dynamics and based on this, a special conservation plan can be made and it should also be included in the working plan for their conservation in the respective habitats. To accomplish the success of such a complex program, a nursery can be raised close to the well identified forest area and these CR/EN/VL plants can be grown there and shall later be transferred to the specific natural habitats. A demo garden can be established along with the interpretation centre which should reflect the mini composition of the entire forest division in respect to rare, endemic, threatened plants of taxonomical, medicinal, trade, cultural and conservation significance.

\section{Acknowledgements}

Authors are thankful to Forest Department of Tamilnadu for funding the project "Status and Survey of Selected CR/EN/DD Taxa in Wild Hosur Forest Division, Tamilnadu", under Tamilnadu Biodiversity and Greening Project (TBGP) scheme activity component 1.1.3.1. Authors are also grateful to Director FRLHT Bangaluru for his support and guidance. Authors are grateful to Late $\mathrm{Mr}$. D. K. Ved (Retd. IFS) for his support, encouragement and technical inputs during the field surveys. We are thankful to our colleagues S. Gokul and N. Dhatchanamoorthy who provided skill and support during data collection and also assisted in data entry. We are also grateful to N. Begum and $\mathrm{N}$. Balachandran for providing their help in the office. We have to express our appreciation to the Mr.Sanjay $\mathrm{K}$. Srivastava, Project Director \& Adl. PCCF and DFO, Hosur and Forest staff for sharing their pearls of wisdom with us during the course of this research. We are also immensely grateful to Dr Manoj Kumar Sarkar, IFS, Adl. PCCF(Retd.) for his comments and support during the course of study.

\section{References}

Ahmedullah M, Nayar MP (1986). Endemic plants of Indian region. Botanical Survey of India, Calcutta.

Anderson MR (1998). International environmental law in Indian courts. Review of European Community \& International Environmental Law $7(1): 21-30$.

Ansari AA (2008). Crotalaria L. India. Bishen Singh Mahendra Pal Singh, DehraDun,pp 978.

Balakrishnan NP, Chakrabarty T (2007). The family Euphorbiaceae in India: a synopsis of its profile, taxonomy and bibliography. Dehra Dun: Bishen Singh Mahendra Pal Singh pp 500.

Balvanera P, Pfisterer BA, Buchmann N, He JS, Nakashizuka T, Raffaelli D, Schmid B (2006). Quantifying the evidence for biodiversity effects on ecosystem functioning and services. Ecology Letters 9(10):1146-1156.

Champion HG, Seth SK (1968). A revised survey of forest types of India. Government of India Press, Delhi, India.

Condit R, Ashton PS, Baker P, Bunyavejohewin S, Gunatileke S, Gunatilleke N, et al., Yamakura T (2000). Spatial patterns in the distribution of tropical tree species. Science 288(5470):14141418.

Curtis JT, McIntosh RP (1950). The interrelations of certain analytic and synthetic phytosociological characters. Ecology 31(3):434-455.

Curtis JT (1959). The Vegetation of Wisconsin, an ordination of plant communities. University Wisconsin Press, Madison, Wisconsin.

Daily CG (1995). Restoring value to the world's degraded lands. Science 269(5222):350-354.

Domboise DM, Ellenberg H (1974). Aims and methods of vegetation ecology.John Wiley \& Sons Inc, New York, pp 449-465.

Gamble JS, Fischer ECE (1915-1935). Flora of the presidencey of Madras. Vols. I-III. Adlard andSon Ltd.,London.

Gopalakrishna SP, Kaonga ML, Somashekar RK, Suresh HS, Suresh R (2015). Tree diversity in the tropical dry forest of Bannerghatta National Park in Eastern Ghats, Southern India. European Journal of Ecology 1(2):12-27.

Henry AN, Kumari GR, Chithra V (1987). Flora of Tamil Nadu, India. Series 1: analysis, Volume 2. Botanical Survey of India, Coimbatore, pp 186.

Henry AN, Chithra V, Balakrishana NP (1989). Flora of Tamil Nadu, India. Series 1: analysis, Volume 3. Botanical Survey of India, Coimbatore.

Hooker,JD (1872-1897). Flora of British India. Volumes 1-7. L. Reeve and Company, Ashford, Kent, U.K. 
606

Hooper DU, Chapin FS, Ewwel JJ, Hector A, Inchausti P, Lavorel S, Wardle DA (2005). Effects of biodiversity on ecosystem functioning: A consensus of currents knowledge. Ecological Monographs 75(1):3-35.

Hubbell SP, Foster RB (1992). Short-term dynamics of a neotropical forest: why ecological research matters to tropical conservation and management. Oikos 63:48-61.

Jagtap AP, Singh NP (1999). Fascicles of flora of India. Botanical Survey of India, Calcutta

Jayakumar S, Soosairaj S, Samy DIA, Britto JS (2002). Similarity analysis in two tropical dry evergreen forests in the Eastern Ghats of Tamil Nadu. Journal of Hill Research 15:411.

Kadavul K, Parthasarathy N (1999). Plant biodiversity and conservation of tropical semi-evergreen in the Shervarayan hills of Eastern Ghats, India. Biodiversity Conservation 8(3):421-439.

Kaya Z, Raynal DJ (2001). Biodiversity and conservation of Turkish forests. Biological Conservation 97(2):131-141.

Matthew KM (1981-1984). The flora of the Tamil Nadu Carnatic. Volumes I-III. The Rapinat Herbarium, St. Joseph's College, Tiruchirapalli.

May RM,StumpfMPH(2000). Species-area relationships in tropical forests. Science 290(5499):20842086.

Myers N, Mittermeier RA, Mittermeier CG, da Fonseca GA, Kent J (2000). Biodiversity hotspots for conservation priorities. Nature 403(6772):853-858.

Naeem S, Wright JP (2003). Disentanging biodiversity effects on ecosystem functioning: deriving solutions to a seemingly insurmountable problem. Ecology Letters 6(6):567-579.

Naidu MT, Kumar OA (2015). Tree species diversity in the Eastern Ghats of northern Andhra Pradesh, India. Journal of Threatened Taxa 7(8):7443-7459.

Nayar MP, Sastry ARK (1987-1990). Red data book of Indian Plants. Volume I-III. Botanical Survey of India, Calcutta.

Nayar MP (1996). "Hot spots" of endemic plants of India, Nepal and Bhutan. Tropical Botanical Garden and Research Institute, Palode, Thiruvananthapuram.

Panda PC, Mahapatra AK, Acharya PK, Debata AK (2013). Plant diversity in tropical deciduous forests of Eastern Ghats, India: A landscape assessment. International Journal of Biodiversity Conservation 5(10):625-639.

Pitchairamu C, Muthuchelian K, Siva (2008). Floristic inventory and quantitative vegetation analysis of tropical dry deciduous forest in Piranmalai forest, Eastern Ghats, Tamil Nadu, India. Ethnobotanical Leaflets 1:25.
Pragasan A, Parthasarathy N (2010). Landscape-level tree diversity assessment in tropical forests of southern Eastern Ghats, India. Flora 205(11):728-737.

Puttakame GS, Kaonga ML, Somashekar RK, Suresh HS, Suresh R (2015). Tree diversity in the tropical dry forest of Bannerghatta National Park in Eastern Ghats, Southern India. European Journal of Ecology 1(2):1227.

Ravikumar K, Ved DK (2000). 100 Red-list medicinal plants of conservation concern in Southern India. Foundation for Revitalisation of Local Health Traditions, Bangalore. Retrieved 27 May 2018 from https://www.iucnredlist.org.

Sagar R, Raghubanshi AS, Singh JS (2003). Tree species composition, dispersion and diversity along a disturbance gradient in a dry tropical forest region of India. Forest Ecology and Management 186(1-3):61-71.

Sanjappa M (1992). Legumes of India. Bishen Singh Mahendra Pal Singh, Dehra Dun, pp 338.

Shannon CE, Wiener W (1963). The mathematical theory of communication. University of Illinois Press, Urbana.

Singh SP (2002). Balancing the approaches of environmental conservation by considering ecosystem services as well as biodiversity. Current Science 82(11):1331-1335.

Sorensen T (1948). A method of establishing groups of equal amplitude in plant sociology based on similarity of species content. Dent Kong Dansk Vindensk(Copenhegen) 5:1-34.

Tiwari UL, Ravikumar K (2018). Floristic diversity, vegetation analysis and threat status of plants in various forest types of Dharmapuri Forest Division, Tamilnadu, Southern India. Notulae Scientia Biologicae 10(2):297-304.

Varma S, Anand VD, Avinash KG, Nishant MS (2009).Ecology, conservation and management of the Asian elephant in Bannerghatta National Park, southern India. A Rocha India/ANCF: Asian Elephant Ecology and Conservation Reference Series 1:13-52.

Villaseñor JL, Maeda P, Rosell JA, Ortiz E (2007). Plant families as predictors of plant biodiversity in Mexico. Diversity and Distributions 13(6):871876.

Wilson EO (1988). The current state of biological diversity. Biodiversity 521(1):3-18. 